\title{
A Institucionalização da Psiquiatria, da Psicanálise e da Psicologia no Brasil
}

\author{
ANA TERESA A. VENANCIO
}

RUSSO, Jane. O Mundo Psi no Brasil. Coleção Descobrindo o Brasil. Rio de Janeiro: Jorge Zahar Editor, 2002. 89 p.

O Mundo Psi no Brasil, que integra a coleção Descobrindo o Brasil, faz parte de um conjunto de publicações escritas por especialistas que abordam temas da história e cultura brasileiras em linguagem acessível a estudantes e ao público em geral. Este é, portanto, o primeiro mérito dessa publicação: traduzir em termos simples a complexa história da constituição e desenvolvimento dos saberes psi no Brasil, sobre a qual a autora vem se debruçando com dedicação já há alguns anos.

Um livro que agrupa o estudo dos chamados saberes psi - psiquiatria, psicologia e psicanálise - confirma antes de tudo a perspectiva de interelação desses três campos de conhecimento: recorrendo às suas linhas de desenvolvimento, Russo expõe com muita exatidão os pontos de contato e linhas de tensão que envolvem a afirmação desses campos no contexto brasileiro, seus objetos e clientela. Para a organização de sua análise, a autora toma a história da psicanálise como eixo condutor privilegiado, tendose em vista a sedução que esse saber exerceu tanto sobre os campos de conhecimento oficiais reconhecidos e controlados pelo Estado - a psiquiatria e a psicologia - quanto sobre a intelectualidade e o público leigo.

A perspectiva adotada demonstra também que os saberes psi e suas práticas terapêuticas não possuem, a priori, fronteiras claramente demarcáveis, como, à primeira vista, nos induz a pensar a crescente especialização dos saberes modernos. Elucida, ao contrário, que a possibilidade de demarcação entre esses representantes dos saberes modernos está implicada pelos processos históricos constitutivos dos mesmos, apresentados de modo cuidadoso nesse livro. Portanto, a história desses saberes é também 
a história do modo como determinadas representações partícipes do ideário moderno adentraram e se consolidaram no imaginário nacional.

A "descoberta" do Brasil por essa via é bem precisa em não fazer do caso brasileiro exemplo de uma mera reprodução dos valores ocidentais modernos ou da conformação dos saberes psi na Europa e nos Estados Unidos. Os processos que, ao menos desde o século XVIII, vêm reconhecidamente produzindo ou sendo produzidos pelas sociedades ocidentais modernas - como a fragmentação dos domínios, a racionalização, a especialização dos saberes, a preeminência do valor-indivíduo e a interiorização do sujeito - são tomados como tendências, que ao aportarem aqui por intermédio dos saberes psi são revestidas de feições próprias. As referências aos desenvolvimentos desses saberes em contextos internacionais específicos constroem, portanto, um quadro expressivo das hegemonias e tensões, demonstrando quais tendências chegaram ao Brasil, quais rumos tomaram e que representações sociais vêm difundindo.

Nesse sentido, Russo aponta como a inauguração do primeiro hospício brasileiro esteve profundamente articulada à afirmação do poder monárquico, enquanto que na França tornara-se símbolo das transformações sócio-políticas relacionadas à Revolução Francesa. Destaca também o fato de a psicanálise no Brasil ter sido difundida a partir do establishment médicopsiquiátrico - diferentemente do contexto europeu, em que as relações entre psicanálise e medicina foram sempre mais ambíguas - indicando as duas vertentes psicanalíticas que aqui se estabeleceram: uma vinculada à ortodoxia e aliada ao autoritarismo, e outra, expressiva, de ideário libertário com ressonância junto à intelectualidade e à classe artística.

A análise da autora segue, com muita propriedade, duas direções complementares. Em primeiro lugar, apresenta as linhas mestras da história da institucionalização desses campos de conhecimento - bem referendada em datas, principais personagens, instituições de ensino e formação - demonstrando como as disputas entre esses atores sociais possibilitaram ou não a afirmação científica e/ou difusão dos saberes psi no Brasil. Em segundo lugar, e implicada pela institucionalização dos saberes psi, dá conteúdo ao modo pelo qual se tem conformado um jogo contrastivo e dinâmico entre abordagens diferenciadas sobre as dimensões física e moral do humano e os males que nos acometem.

A exposição desse complexo objeto de estudo - o mundo psi - não destitui o texto, no entanto, de clareza e objetividade. Partindo de uma ordenação cronológica, que se inicia pela constituição da psiquiatria no Bra- 
sil, a autora se detém nas relações entre psiquiatria e psicanálise para, em seguida, estabelecer um diálogo entre tais relações e o surgimento do que chama de "novos atores". Russo expõe então como a psicologia e seus representantes conseguem aqui se estabelecer, tendo-se em vista o embate tanto com a classe médica, como com a intelectualidade católica, inicialmente reticente em relação ao "estudo 'materialista' da mente humana".

As inflexões temporais e de inte-relação entre esses três saberes, considerando-se um certo "mercado" de produtores e consumidores em torno do cuidado laico e "científico" da alma e do corpo, atravessa a exposição do que ocorre a partir dos anos 70 do século XX. Como denomina a própria autora, a busca desenfreada do divã, os "tapas e beijos" entre psicanalistas e psicólogos, o surgimento do lacanismo, os embates entre as terapias do corpo e as da palavra, os momentos de difusão e de construção de ortodoxia das chamadas terapias corporais, a entrada do ideário antipsiquiátrico no Brasil e a recente rebiologização da psiquiatria e do humano compõem a complexa rede de relações dinâmicas que dá forma ao chamado mundo psi. A análise dessas relações ganha ainda quadros elucidativos sobre a proliferação de sociedades de formação em psicanálise no Rio de Janeiro e de sociedades "independentes" após o boom de difusão dos anos de 1970, seguidos de uma cronologia sintética e de sugestões para leitura.

O livro O Mundo Psi no Brasil, portanto, sintetiza de modo inteligente e accessível a história da psiquiatria, da psicanálise e da psicologia em nosso meio, apontando a importância dos mesmos para a afirmação de representações e práticas sociais que têm informado nosso imaginário. Compreender o modo como esses saberes laicos sobre o humano entram e se difundem em solo brasileiro é ampliar nossa visão sobre as vias pelas quais a sociedade brasileira se apropriou de aportes e paradigmas considerados "modernos". A difusão de tais aportes, como bem demonstra a autora, tem sido ao mesmo tempo constitutiva e constituída por atores sociais, cujas práticas e concepções variadas dialogam sobre o que devemos entender como próprio do indivíduo, sobre o estatuto de suas dimensões física e moral, os sentidos concedidos ao adoecimento e as terapêuticas a eles correspondentes. Indica-nos, assim, que a institucionalização dos saberes psi - expressiva da entrada e afirmação da configuração de valores individualistas no contexto brasileiro - trouxe para parte da cena nacional modos de incorporação e difusão de explicações sobre a vida fundados na interioridade, escolha e realização individual. Modos esses comparativamente diferenciados de re- 
presentações tradicionais, em que a filiação e o pertencimento a grupamentos de classe, raça e religião são os eixos privilegiados para situar o humano e seus males no mundo.

\section{NOTA}

1 Doutora em Antropologia Social pelo Museu Nacional/UFRJ. Professora visitante do Instituto de Psiquiatria da Universidade Federal do Rio de Janeiro. 